\title{
Cadmium Pollution in the Tourism Environment: A Literature Review
}

\author{
Anna V. Mikhailenko ${ }^{1}$, Dmitry A. Ruban ${ }^{2,3, * \mathbb{C}}$, Vladimir A. Ermolaev ${ }^{4}$ \\ and A.J. (Tom) van Loon 5 (D) \\ 1 Department of Physical Geography, Ecology, and Nature Protection, Institute of Earth Sciences, \\ Southern Federal University, Zorge Street 40, 344090 Rostov-on-Don, Russia; avmihaylenko@sfedu.ru \\ 2 K.G. Razumovsky Moscow State University of Technologies and Management (the First Cossack University), \\ Zemlyanoy Val Street 73, 109004 Moscow, Russia \\ 3 Department of Hospitality Business, Higher School of Business, Southern Federal University, \\ 23-ja Linija Street 43, 344019 Rostov-on-Don, Russia \\ 4 Department of Commodity Science and Expertise, Plekhanov Russian University of Economics, \\ Stremyanny Lane 36, 117997 Moscow, Russia; ermolaevvla@rambler.ru \\ 5 College of Earth Science and Engineering, Shandong University of Science and Technology, \\ Qingdao 266590, Shandong, China; Geocom.VanLoon@gmail.com \\ * Correspondence: ruban-d@mail.ru
}

Received: 12 May 2020; Accepted: 18 June 2020; Published: 22 June 2020

\begin{abstract}
Cadmium is a highly-toxic metal, and, its environmental occurrence and human exposure consequently deserve close attention. The insight into the relationships between cadmium and tourism relations has deepened during the past three decades and the research into this relationship is reviewed. For this purpose, 83 relevant publications (mainly articles in international journals) were analyzed. It was found that investigation of $\mathrm{Cd}$ in the tourism environment took place in all continents (except Antarctica) and has intensified since the mid-2000s; Chinese researchers are the most active contributors. The Cd occurrence in air, living organisms, sediments, soil, suspended particular matter, water, and of the human environment has been studied. It has become clear that tourism contributes to Cd pollution (particularly, by hotel wastewater and increased traffic), and, vice versa, Cd pollution of beaches, coastal waters, food, urban parks, etc. creates risks for tourists and increases human exposure to this toxic metal. Both mechanisms have received equal attention. Examples concern many places worldwide, with the Mediterranean and Central and Eastern Europe as apparently critical regions. Our significantly incomplete knowledge of the relationships between cadmium and tourism must be ascribed to the common oversimplification of these relationships and to the scarcity or even absence of information supplied by the most important tourist destinations. The present review demonstrates that more studies of heavy metals and, particularly, $\mathrm{Cd}$ in the tourism environment are needed.
\end{abstract}

Keywords: bibliographical survey; food; heavy metals; human exposure; pollution; research focus; tourist destinations

\section{Introduction}

Tourism affects large areas in many parts of the world, including ocean and sea shores (beach resorts), tropical forests and wetlands (national parks for ecotourists), and mountainous areas (ski resorts). These areas experience not only crowding by numerous visitors, but also physical modification (artificial beaches, recreation zones, transport infrastructure, etc.). Tourism already requires more than $50,000 \mathrm{~km}^{2}$ worldwide, and the areal demand from this industry might almost duplicate in the future [1]. It thus seems that a new type of environment, namely 
the tourism environment, has been created (see terminology in [2-6]). This new environment is characterized by the co-existence of both natural and original cultural components with tourism-specific constructions and (almost) permanent people over-crowding. The tourism environment is not a classical human-affected or artificial environment, because it requires specific approaches of environmental management [7] and even a change of the very meaning of the local landscape (e.g., 'tourisming' coastlines [8]).

The local, national, and global environmental effects of tourism are undisputable, and research has been focused on them for several decades [9-19]. Although negative effects are often emphasized, there is also evidence that tourism contributes to a better environmental performance of economic systems and society [20-22]. Much attention is paid nowadays to the contribution of tourism to greenhouse gas emissions and climate change [23-29], but the relationship between tourism and environment is much more diverse; it is highly complex with unexpected aspects. For instance, sport shooting in the United Kingdom is responsible for significant $\mathrm{Pb}$ pollution of agricultural land [30]. More generally, the contribution of tourism to heavy metal pollution, and the importance of the latter for key tourism resources (beach sand, water, etc.) have become important research topics [31-35]. Unfortunately, the relevant information is scattered over hundreds of publications (often based on case studies), and it still lacks systematization.

Among heavy metals, cadmium $\left({ }^{48} \mathrm{Cd}\right.$, commonly present in its $\mathrm{Cd}(\mathrm{II})$ state) is relatively widely distributed in nature (air, living organisms, sediment, soil, water) and in man-affected sphere (agricultural crop, food, sewage sludge), and it is also actively taken up by crops. This is dangerous because of its significant toxicity, posing a risk for human health, even in minimal concentrations [36-59]. The concentration of this metal in the environment is low, but it tends to accumulate in living organisms, including the human body. In the biosphere, this metal tends to disperse (organisms do not tend to accumulate it due to its toxicity), but various anthropogenic activities can lead to its concentration. Humans are exposed to $\mathrm{Cd}$ chiefly through the food chain, i.e., via consumption of contaminated crops and other natural products, and exposure also depends on the persistence of the dietary intake of this metal. Cd sources can be both natural (Cd concentration in the natural environment) and anthropogenic (brought into the landscape through phosphate fertilizers, produced by mining, and released via municipal wastewater); mixed mechanisms of $\mathrm{Cd}$ pollution are air transport of human-triggered $\mathrm{Cd}$ emissions and subsequent deposition [57]. Although Cd pollution and tourism seem to be far-standing issues, their relationships can be hypothesized. For instance, higher concentrations of $\mathrm{Cd}$ in food offered in popular tourist destinations increases human exposure to this toxic metal, whereas hotel wastewater can contribute to $\mathrm{Cd}$ pollution.

The main objective of this study was to systematize the available, but fragmented and scattered information about the cadmium-tourism relationships, on the basis of published data. This synthesis also shows some lacking data, which might initiate future investigations. From a practical point of view, the present review might help both specialists in environmental management who need to be aware of the specific aspects of tourism environments and experts in tourism management (not experts in environmental geochemistry) who need an overview of the present-day insights into the relevance of $\mathrm{Cd}$ for tourism activities.

\section{Collecting Literature: A Methodological Outline}

The present contribution is based on analysis of the available open literature, mainly articles in international journals. Some general principles of such studies are explained in the works by Fernandez [60], Koons et al. [61], Pati and Lorusso [62], Rewhorn [63], Snyder [64], Sovacool et al. [65], and Wee and Banister [66], and these are partly followed here. The present study is, however, not meant to be a complete bibliometrical analysis but rather is based on the on-line bibliographical database 'Scopus', in order to include a representative amount of the literature. The size of this database implied that it includes the majority of the main sources, i.e., articles in top international journals, as well as many 'secondary-order' sources, i.e., publications in national journals, including 
some published in languages other than English (Chinese, French, Japanese, Polish, Russian, etc.). The database was accessed in March 2020 to collect as many studies relevant for Cd in tourism environments (with the relevant terms in titles, abstracts, keywords) as possible (all years and all types of papers were addressed). The search yielded 68 studies on $\mathrm{Cd}$ and tourism, 87 studies on $\mathrm{Cd}$ and recreation, 11 studies on $\mathrm{Cd}$ and hotels, and 4 studies on $\mathrm{Cd}$ and hospitality. These studies were filtered to avoid duplications and to exclude non-relevant data. As a result, 83 studies dealing with the cadmium-tourism relationships were selected (Table 1). Undoubtedly, this list is incomplete (as no bibliographical database can be 100\% complete), but it might safely be presumed that it includes the majority of the principal works.

Table 1. Basic information on the studies considered in the present review.

\begin{tabular}{|c|c|c|c|c|c|}
\hline Source & Author Country & Focus on Cd & $\begin{array}{l}\text { Focus on } \\
\text { Tourism }\end{array}$ & $\begin{array}{l}\text { Focus on } \\
\text { Country }\end{array}$ & Relation* \\
\hline Ahdy and Youssef [67] & Egypt & no & no & Egypt & $\mathrm{Cd}->\mathrm{T}$ \\
\hline Akcay et al. [68] & Turkey & yes & no & Turkey & $\mathrm{T}->\mathrm{Cd}(\mathrm{p})$ \\
\hline Alomary and Belhadj [69] & Jordan & yes & no & Algeria & $\mathrm{T}->\mathrm{Cd}$ \\
\hline Alonso Castillo et al. [70] & Spain & no & no & Spain & $\mathrm{T}->\mathrm{Cd}$ \\
\hline Anhichem et al. [71] & Morocco & no & no & Morocco & $\mathrm{T}->\mathrm{Cd}(\mathrm{p})$ \\
\hline Baktybaeva et al. [72] & Russia & no & no & Russia & $\mathrm{Cd}->\mathrm{T}$ \\
\hline Bencko [73] & Czechia & no & no & Czechia & $\mathrm{Cd}->\mathrm{T}$ \\
\hline Bharagava et al. [74] & India & no & no & India & $\mathrm{Cd}->\mathrm{T}(\mathrm{pr})$ \\
\hline $\begin{array}{l}\text { Bhumibhamorn } \\
\text { and Visuthismajarn [75] }\end{array}$ & Thailand & no & yes & Thailand & $\mathrm{Cd}->\mathrm{T}(\mathrm{p})$ \\
\hline Bohari and Palutturi [76] & Indonesia & no & no & Indonesia & $\mathrm{Cd}->\mathrm{T}(\mathrm{p})$ \\
\hline Böhlandt et al. [77] & Germany & no & no & Germany & $\mathrm{T}->\mathrm{Cd}$ \\
\hline Bolte et al. [78] & Germany & no & no & Germany & $\mathrm{Cd}->\mathrm{T}$ \\
\hline Darmody et al. [79] & USA & no & no & USA & $\mathrm{T}->\mathrm{Cd}(\mathrm{p})$ \\
\hline De Roma et al. [80] & Italy & yes & no & Italy & $\mathrm{Cd}->\mathrm{T}$ \\
\hline Demirak et al. [81] & Turkey & no & no & Turkey & $\mathrm{T}->\mathrm{Cd}$ \\
\hline Eddaoudi et al. [82] & Morocco & no & no & Morocco & $\mathrm{Cd}->\mathrm{T}(\mathrm{p})$ \\
\hline El Ati-Hellal et al. [83] & Tunisia & yes & no & Tunisia & $\mathrm{T}->\mathrm{Cd}(\mathrm{p})$ \\
\hline Fan et al. [84] & China & yes & no & China & $\mathrm{Cd}->\mathrm{T}(\mathrm{m})$ \\
\hline Fitzmorris et al. [85] & USA & no & no & USA & $\mathrm{Cd}->\mathrm{T}(\mathrm{pr})$ \\
\hline Frimpong and Koranteng [86] & Ghana & no & yes & Ghana & $\mathrm{Cd}->\mathrm{T}$ \\
\hline Garcia et al. [87] & Venezuela & no & no & Venezuela & $\mathrm{T}->\mathrm{Cd}$ \\
\hline Geghamyan and Pavlickova [88] & Slovakia & no & yes & Armenia & $\mathrm{Cd}->\mathrm{T}$ \\
\hline Gidarakos et al. [89] & Greece & no & no & Greece & $\mathrm{T}->\mathrm{Cd}$ \\
\hline Gladyshev et al. [90] & Russia & no & no & Russia & $\mathrm{Cd}->\mathrm{T}(\mathrm{p})$ \\
\hline Gonzalez et al. [91] & Spain & no & no & Morocco & $\mathrm{T}->\mathrm{Cd}(\mathrm{p})$ \\
\hline Hassan et al. [92] & $\mathrm{UAE}$ & no & no & UAE & $\mathrm{T}->\mathrm{Cd}(\mathrm{p})$ \\
\hline Ivankovic et al. [93] & Croatia & no & yes & Croatia & $\begin{array}{l}\mathrm{T}->\mathrm{Cd} \\
\mathrm{Cd}->\mathrm{T}\end{array}$ \\
\hline Jahan and Strezov [94] & Australia & no & no & Australia & $\mathrm{T}->\mathrm{Cd}$ \\
\hline Jeszke et al. [95] & Poland & yes & no & Poland & $\mathrm{Cd}->\mathrm{T}(\mathrm{p})$ \\
\hline Ji et al. [96] & $\begin{array}{l}\text { China, USA, } \\
\text { Belgium }\end{array}$ & no & yes & China & $\mathrm{T}->\mathrm{Cd}$ \\
\hline Jonathan et al. [97] & Mexico, India & no & yes & Mexico & $\mathrm{T}->\mathrm{Cd}$ \\
\hline Joy et al. [98] & India & no & no & India & $\mathrm{T}->\mathrm{Cd}$ \\
\hline Joy et al. [99] & India & no & no & India & $\mathrm{T}->\mathrm{Cd}$ \\
\hline Kawecka-Radomska et al. [100] & Poland & no & yes & Poland & $\begin{array}{l}\mathrm{T}->\mathrm{Cd} \\
\mathrm{Cd}->\mathrm{T}\end{array}$ \\
\hline
\end{tabular}


Table 1. Cont.

\begin{tabular}{|c|c|c|c|c|c|}
\hline Source & Author Country & Focus on Cd & $\begin{array}{l}\text { Focus on } \\
\text { Tourism }\end{array}$ & $\begin{array}{l}\text { Focus on } \\
\text { Country }\end{array}$ & Relation* \\
\hline LaValle et al. [101] & Canada & no & no & Canada, USA & $\mathrm{Cd}->\mathrm{T}$ \\
\hline Li et al. [102] & China & no & yes & China & $\mathrm{Cd}->\mathrm{T}$ \\
\hline Li et al. [103] & China & no & no & China & $\mathrm{Cd}->\mathrm{T}(\mathrm{p})$ \\
\hline Liu et al. [104] & China & no & no & China & $\mathrm{Cd}->\mathrm{T}$ \\
\hline Liu et al. [105] & China, Pakistan & no & no & Pakistan & $\mathrm{T}->\mathrm{Cd}$ \\
\hline Macdonald et al. [106] & Canada & no & no & Arctic & $\mathrm{T} \times \mathrm{Cd}$ \\
\hline Macleod and Coughanowr [107] & Australia & no & no & Australia & $\mathrm{Cd}->\mathrm{T}$ \\
\hline Mali et al. [108] & Italy & no & yes & Italy & $\mathrm{T}->\mathrm{Cd}$ \\
\hline Martinez-Soto et al. [109] & Spain & no & no & Spain & $\mathrm{T}->\mathrm{Cd}$ \\
\hline Mikac et al. [110] & Croatia & no & no & Croatia & $\mathrm{T}->\mathrm{Cd}(\mathrm{p})$ \\
\hline Miskowiec et al. [111] & Poland & no & no & Poland & $\mathrm{Cd}->\mathrm{T}$ \\
\hline Nikolic et al. [112] & Serbia & no & no & Serbia & $\mathrm{T}->\mathrm{Cd}(\mathrm{p})$ \\
\hline Nilsen et al. [113] & USA & no & no & USA & $\mathrm{Cd}->\mathrm{T}$ \\
\hline Nour [114] & Egypt & no & no & Egypt & $\mathrm{T}->\mathrm{Cd}$ \\
\hline Paixao et al. [115] & Brazil & no & no & Brazil & $\mathrm{T}->\mathrm{Cd}$ \\
\hline Pena-Fernandez et al. [116] & Spain & no & no & Spain & $\mathrm{Cd}->\mathrm{T}(\mathrm{p})$ \\
\hline Peng et al. [117] & China & no & no & China & $\mathrm{Cd}->\mathrm{T}(\mathrm{p})$ \\
\hline Persson et al. [118] & Sweden & no & no & Sweden & $\mathrm{Cd}->\mathrm{T}$ \\
\hline Pip [119] & Canada & no & no & Canada & $\mathrm{T}->\mathrm{Cd}(\mathrm{p})$ \\
\hline Pourabadehei and Mulligan [120] & Canada & no & no & Canada & $\mathrm{T}->\mathrm{Cd}$ \\
\hline Prego and Cobelo-Garcia [121] & Spain & no & no & Spain & $\mathrm{T}->\mathrm{Cd}(\mathrm{p})$ \\
\hline Pruekparichart et al. [122] & Thailand & no & yes & Thailand & $\mathrm{T}->\mathrm{Cd}(\mathrm{pr})$ \\
\hline Rajan et al. [123] & Malaysia & no & yes & Malaysia & $\mathrm{Cd}->\mathrm{T}(\mathrm{p})$ \\
\hline Ramessur et al. [124] & Mauritius, UK & no & yes & Mauritius & $\mathrm{T}->\mathrm{Cd}(\mathrm{p})$ \\
\hline Rybakov [125] & Russia & no & no & Russia & $\mathrm{Cd}->\mathrm{T}$ \\
\hline Rzetala et al. [126] & Poland & no & yes & Czechia & $\mathrm{Cd}->\mathrm{T}(\mathrm{p})$ \\
\hline Rzymski et al. [127] & Poland & no & no & Poland & $\mathrm{Cd}->\mathrm{T}$ \\
\hline Salvado et al. [128] & Spain & no & no & Spain & $\mathrm{T}->\mathrm{Cd}$ \\
\hline Saxena and Saiful-Arfeen [129] & India & no & no & India & $\mathrm{T}->\mathrm{Cd}$ \\
\hline Shafiq et al. [130] & Pakistan & no & no & Pakistan & $\mathrm{Cd}->\mathrm{T}$ \\
\hline Shakir et al. [131] & Pakistan, UK & no & no & Pakistan & $\mathrm{Cd}->\mathrm{T}$ \\
\hline Shi et al. [132] & China & no & yes & China & $\mathrm{Cd}->\mathrm{T}$ \\
\hline Shine et al. [133] & USA & no & no & Mexico & $\mathrm{Cd}->\mathrm{T}$ \\
\hline Shparyk and Parpan [134] & Ukraine & no & no & Ukraine & $\mathrm{T} \times \mathrm{Cd}$ \\
\hline Song et al. [135] & China, Australia & no & no & China & $\mathrm{T}->\mathrm{Cd}(\mathrm{p})$ \\
\hline Sun et al. [136] & China & yes & no & China & $\mathrm{Cd}->\mathrm{T}(\mathrm{m})$ \\
\hline Sylaios et al. [137] & Greece & no & no & Greece & $\mathrm{T}->\mathrm{Cd}(\mathrm{p})$ \\
\hline Timofeev et al. [138] & Russia & no & no & Mongolia & $\mathrm{T}->\mathrm{Cd}(\mathrm{p})$ \\
\hline Torres et al. [139] & Portugal & no & no & Portugal & $\mathrm{Cd}->\mathrm{T}$ \\
\hline Umunnakwe John Bosco et al. [140] & Nigeria & no & no & Nigeria & $\mathrm{Cd}->\mathrm{T}$ \\
\hline $\begin{array}{c}\text { Valdelamar-Villegas } \\
\text { and Olivero-Verbel [141] }\end{array}$ & Colombia & no & no & Colombia & $\mathrm{T} \times \mathrm{Cd}$ \\
\hline Varkouhi [142] & Iran & no & no & Iran & $\mathrm{T} \times \mathrm{Cd}$ \\
\hline Veiga et al. [143] & Portugal & no & no & Portugal & $\mathrm{T}->\mathrm{Cd}(\mathrm{p})$ \\
\hline
\end{tabular}


Table 1. Cont.

\begin{tabular}{cccccc}
\hline Source & Author Country & Focus on Cd & $\begin{array}{c}\text { Focus on } \\
\text { Tourism }\end{array}$ & $\begin{array}{c}\text { Focus on } \\
\text { Country }\end{array}$ & Relation* \\
\hline Vetrimurugan et al. [144] & $\begin{array}{c}\text { South Africa, } \\
\text { Mexico }\end{array}$ & no & yes & South Africa & T->Cd (p) \\
\hline Vetrimurugan et al. [145] & $\begin{array}{c}\text { South Africa, } \\
\text { Mexico }\end{array}$ & no & yes & South Africa & T->Cd \\
\hline Wang et al. [146] & China, USA & no & no & China & Cd->T (p) \\
\hline Wei et al. [147] & China & no & no & China & T->Cd \\
\hline Yalcin and Ilhan [148] & Turkey & no & no & Turkey & T->Cd (p) \\
\hline Yang et al. [149] & China & no & yes & China & Cd->T \\
\hline
\end{tabular}

Note: ${ }^{*} \mathrm{~T}->\mathrm{Cd}$-tourism contributes to $\mathrm{Cd}$ pollution; $\mathrm{Cd}->\mathrm{T}-\mathrm{Cd}$ pollution creates risks for tourism; $\mathrm{T} \times \mathrm{Cd}$-absence of any direct dependence; $\mathrm{p}$ - 'positive' evidence; $\mathrm{pr}$ - prevention; $\mathrm{m}$ - methodology (see text for more explanations).

The content of each work considered for the purposes of the present review was analyzed on the basis of two major categories, namely research parameters and research findings. Criteria of the first category allow judging whether a given work is focused on $\mathrm{Cd}$ or tourism (this could be determined provisionally from the work's title), when it was published, and which countries were represented by its authors. Criteria of the second category enabled analyzing the geographical distribution of the reviewed research by countries and environmental components, the mechanism discussed in the works (see below), and the main research topics (these can be defined intuitively as a result of a synthesis of the available literature). As hypothesized above, tourism can trigger Cd pollution, and $\mathrm{Cd}$ pollution can affect tourism activities. Additionally, some works can deal with both tourism and $\mathrm{Cd}$, but without direct links. Consequently, three cadmium-tourism relationships (mechanisms) might be the research focus of the literature under study (Figure 1). Preliminary analysis of the collected studies confirmed this idea. Moreover, it was found that some works provided 'positive' evidence. This meant that either $\mathrm{Cd}$ pollution was studied, but not found, or that the Cd content was below dangerous levels, or that it was not the main pollutant. Moreover, some studies could be essentially methodological or focused on prevention of negative processes. All these peculiarities of the research focus were also documented. The analysis of the works on the basis of the above-mentioned criteria allowed some generalizations and subsequent interpretations that represent the available knowledge about the relationships between cadmium and tourism in a systematic way.

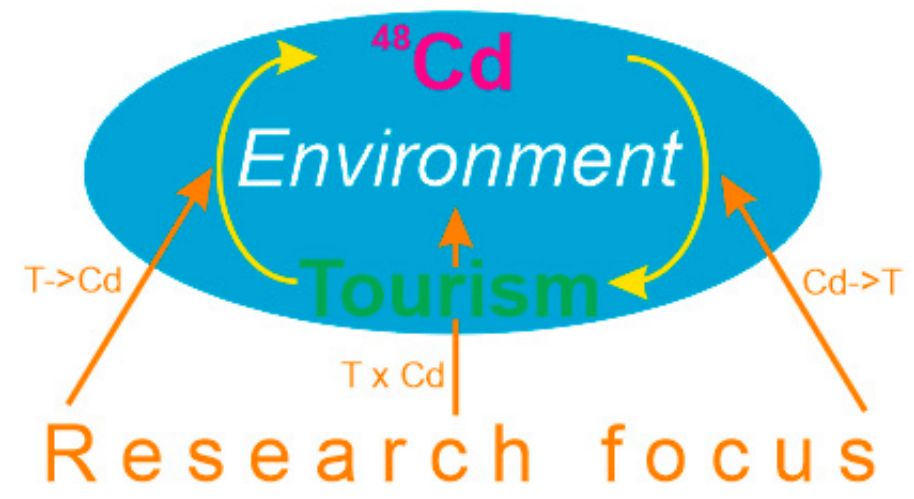

Figure 1. The three main subjects of research in the cadmium-tourism relationships.

\section{Synthesis of Research Parameters}

A total of only 83 articles on the cadmium-tourism relationships published during 32 years ( 2.6 articles per year) suggest relatively little research into this subject (Table 1$)$. However, taking into account how 'narrow' and specific the subject is, the number of articles must be considered as relatively large. This implies that the cadmium-tourism relationships were of some interest to 
the international research community. From all considered studies, $8 \%$ focused on $\mathrm{Cd}$ and $20 \%$ focused on tourism (Table 1). None of the publications focused on both $\mathrm{Cd}$ and tourism, and the majority of the articles dealt with environmental issues that were less specific than the cadmium-tourism relationships. These findings indicate that despite its relative importance, the subject under review remained rather 'marginal', and that the cadmium-tourism relationships were mainly considered 'incidentally', e.g., in the context of local environmental assessment studies.

The frequency of publications on the subject changed over time (Figure 2). The earliest publication included in the present review dated from 1989; the 1990s were characterized by low research interest into the subject. The situation changed drastically in the mid-2000s, when the number of studies started to grow. This tendency persisted until now, although the dynamics remained unstable (Figure 2). The largest number of studies were published in the second half of the 2010s. Although one could hypothesize that the described distribution over time of the considered studies was affected by incomplete bibliographical data (also due to the lower coverage of pre-2000 works), the increase since the mid-2000s was clear, whereas these 'recent' works were well-covered by 'Scopus'. The acceleration of the research in the cadmium-tourism relationships thus seemed to be a real tendency, although with ups and downs.

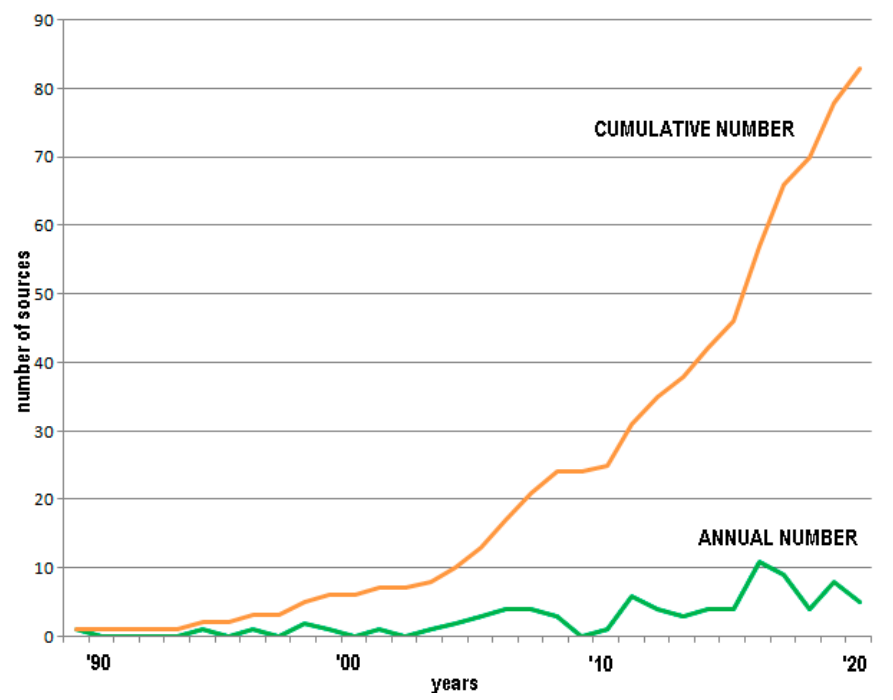

Figure 2. Distribution of the studies under review by year of publication. See Table 1 for data. The first three months were considered for 2020.

The importance of the cadmium-tourism relationships was demonstrated well by the geographical spreading of the authors of the studies under review (Figure 3). Researchers from Europe, the Middle East, southeastern Asia, the Americas, and Australia have all paid attention to this subject, i.e., the research was truly international. The majority of studies were published by researchers from China (16\% of the studies), Spain and the USA (7\% each), and India and Poland (6\% each). The absence of studies by Japanese researchers was surprising because the influence of $\mathrm{Cd}$ pollution on human health is best known from this country [45]. One should also note the low degree of international collaboration. Only $11 \%$ of the works were written by the authors from two or more countries (only one study was written by authors from three countries). Chinese and, to a lesser degree, Mexican specialists seemed to be the most active international collaborators. Generally, the geographical spread of the authors indicates the absence of a 'mature' international research network. 


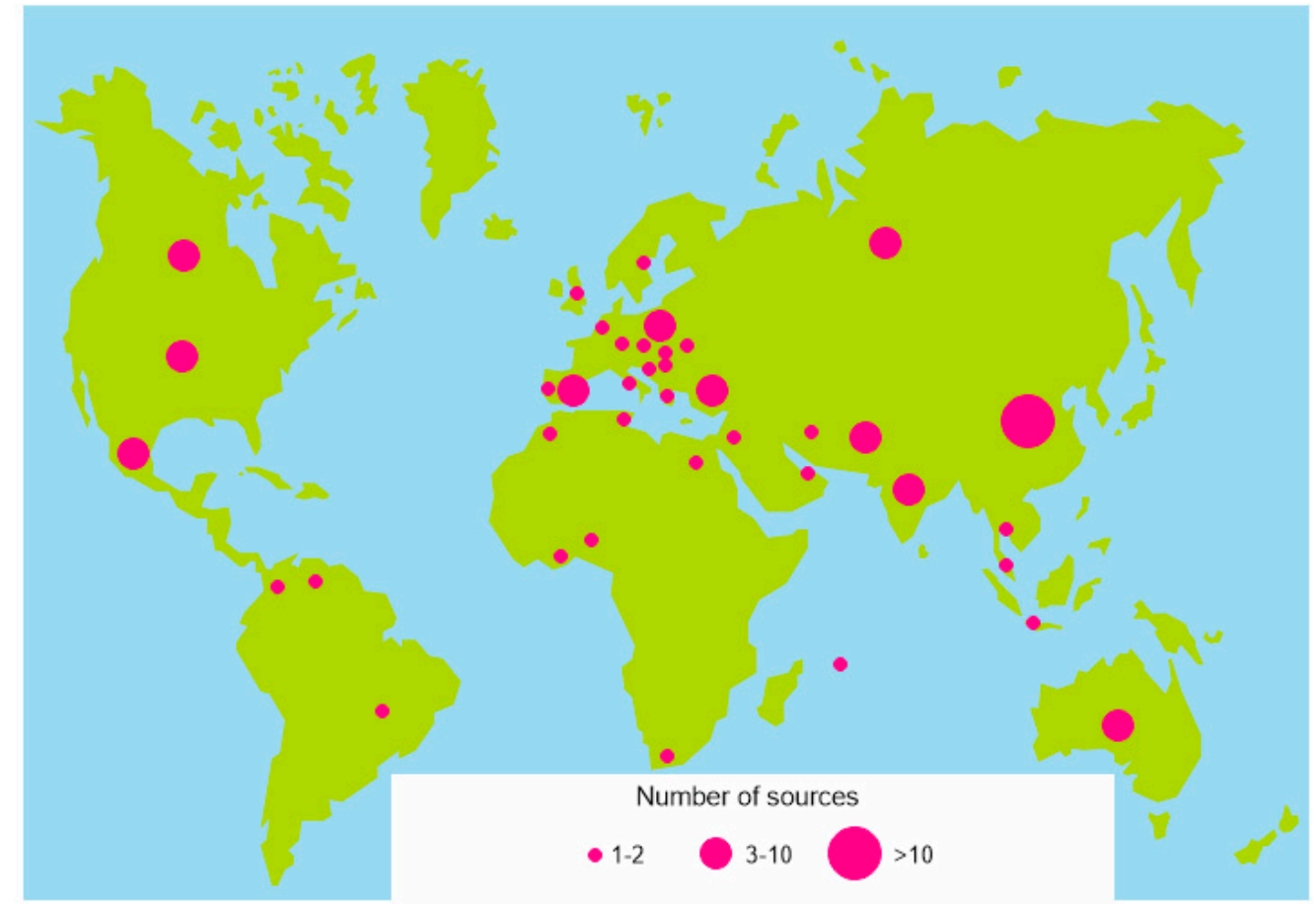

Figure 3. Geographical spreading of the authors of the studies under review. See Table 1 for data.

\section{Synthesis of Research Findings}

Tourism environments are globally widespread, and they include-but are not limited to-resort zones at sea coasts and in mountains, regions with a rich culture and history, and recreation areas in forests and along rivers. All countries have more or less important tourism resources [150]. The reviewed literature makes it clear in which of these countries the cadmium-tourism relationships were studied. Although this did not (and cannot) reflect the true geographical distribution of $\mathrm{Cd}$ in the tourism environment due to 'natural' research biases, these findings were important because they showed the global significance of the problem. Numerous countries formed the focus of the studies (Figure 4). The cadmium-tourism relationships have been studied on all continents, except Antarctica. China (14\% of the studies) and Spain $(6 \%)$ are the countries that have attracted most attention. One should note, however, that interest in this research topic has remained low in Western Europe and South America. This meant that although the cadmium-tourism relationships were studied worldwide, including developing countries, the scope of the considered studies was mainly local, and none of the studies focused on more than one country (except for the study by Macdonald et al. [106] which dealt with the entire Arctic).

The cadmium-tourism relationships were traced for the different components of the environment, among which the best studied were water, sediments, and soil (Table 2). Importantly, anthropogenic components were also involved in the cadmium-tourism relationships. One should also note that numerous studies examined the entire landscape (Table 2). Apparently, $\mathrm{Cd}$ cycles in the tourism environment are complex, and they included not only the concentration of this metal in any particular component (e.g., soil or water), but also its dispersal in the entire environment, uptake by organisms, and direct exposure to it by tourists.

Different mechanisms were analyzed in the articles under review (Table 1). Roughly the same number of studies dealt with the influences of $\mathrm{Cd}$ pollution on tourism $(48 \%)$ and the contribution by tourism to Cd pollution ( $49 \%)$; in two papers, both mechanisms were considered. A few studies (5\%) did not address direct relationships. Some $28 \%$ of the studies dealing with influences of $\mathrm{Cd}$ pollution on tourism bore 'positive' evidence, while $41 \%$ of the studies dealing with the contribution of tourism to $\mathrm{Cd}$ pollution bore 'positive' evidence. These results meant that tourism triggered $\mathrm{Cd}$ pollution 
and that $\mathrm{Cd}$ pollution commonly affected tourism activities; both relationships received adequate scientific investigation. It was also evident that the presence of $\mathrm{Cd}$ in the tourism environment was, in a significant number of cases, not linked to the risks, although cases with such risks were numerous. Most available literature supports the idea that the relationship between cadmium and tourism deserve attention, as they dealt with an increased tourist exposure to this toxic metal.

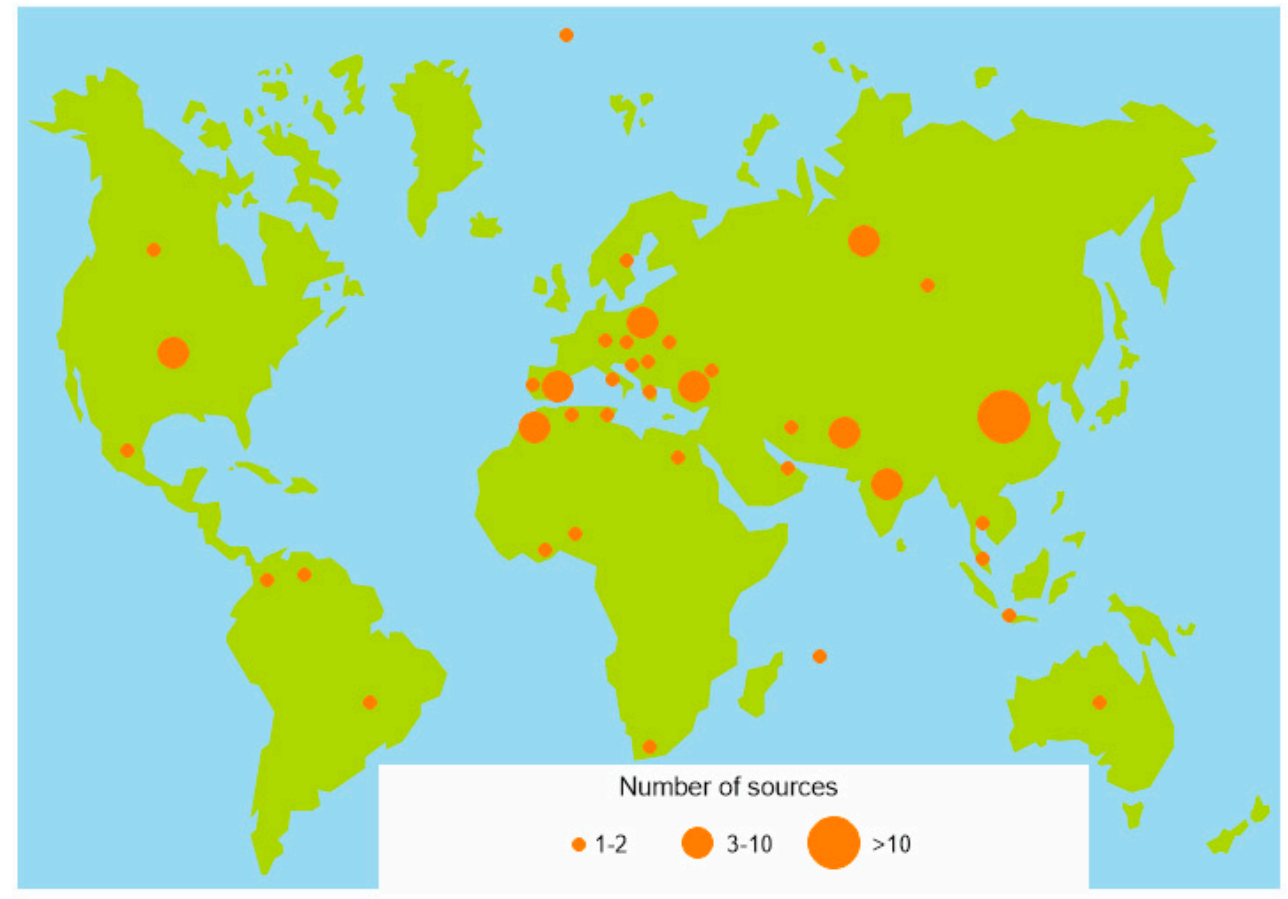

Figure 4. Geographical spread of the studies under review. See Table 1 for data.

Although the only internationally-reported examples of these relationships were considered in the present review, their worldwide distribution shed light on the geographical patterns of these mechanisms. The contribution of tourism to $\mathrm{Cd}$ pollution was found in many countries of the world (Figure 5A). A concentration was found in the Mediterranean countries (Algeria, Croatia, Egypt, Greece, Italy, Spain, and Turkey). This is not unexpected, considering the intensity of tourism and the consequent anthropogenic pressure here [151-156]. Cd pollution creating risks for tourism has been established widely, but not in South America (Figure 5B). Examples tend to concentrate in Central and Eastern Europe, which could be explained tentatively by post-industrial shifts [157,158], when heavily-affected areas became important for recreation.

Thematically, the considered studies were very diverse, and they addressed both general and highly-specific issues. Three points in particular needed attention. The first one was that numerous studies discussed tourist exposure to $\mathrm{Cd}$ pollution, particularly on beaches and in restaurants. For instance, Nour [114] addressed Cd in recent beach sediments at Sharm El-Sheikh, a world-famous Egyptian resort, and found that the concentration of this metal was very high, also in comparison to other recreation areas in Egypt, Saudi Arabia, and Russia. Moreover, he demonstrated that tourism constituted the main source of this pollution. In another study, Torres et al. [139] demonstrated that tourism growth on the Azores made Haliotis tuberculata an important food resource, although higher-than-normal levels of $\mathrm{Cd}$ in this organism posed risks to human health. Second, some studies have indicated wastewater, including that of hotels, as a source of Cd pollution. This was documented in particular by Eddaoudi et al. [82] for the Agadir Bay (Morocco) and the same was forecasted for the nearest future by Liu et al. [105] for the Swat River (Pakistan). Third, it is sensible to emphasize that several studies pay attention to $\mathrm{Cd}$ pollution in urban recreation areas and along roads. These include studies by Ji et al. [96] on the effects of the Chinese Spring Festival on air pollution, Li et al. [102] on 
Cd pollution along the roads in the Beijing Olympic Park, and Wang et al. [146] on the traffic-related pollution on the Tibetan Plateau, where heavy metals pollute 'stripes' up to dozens of meters wide along highways.

Table 2. Principal environmental components relevant to the cadmium-tourism relationships in the studies under review.

\begin{tabular}{|c|c|c|}
\hline Component & Details & Sources \\
\hline Air & Not specified & [96] \\
\hline \multirow{5}{*}{ Anthropogenic } & Not specified & {$[77,78,122]$} \\
\hline & Dust & {$[102,132,147]$} \\
\hline & Food & [80] \\
\hline & Water & {$[85,117]$} \\
\hline & Waste & [89] \\
\hline Entire landscape & Not specified & {$[72,74,82,88,90,106,107,121,124,134]$} \\
\hline \multirow{4}{*}{ Living organisms } & Fresh water & {$[75,112,127,128,130,142]$} \\
\hline & Marine & {$[83,93,115,135,139,141]$} \\
\hline & Terrestrial & {$[68,79,125,129]$} \\
\hline & Wetland & [113] \\
\hline \multirow{5}{*}{ Sediments } & Beach & {$[71,97,114,144,145,148]$} \\
\hline & Bottom & $\begin{array}{c}{[67,70,81,87,91,101,104,105,108,109,112,120,126,127,} \\
131,137,140]\end{array}$ \\
\hline & Coral reef & {$[98,99]$} \\
\hline & Lagoon & [143] \\
\hline & Surface & {$[69,128]$} \\
\hline Soil & Not specified & {$[86,100,103,111,116,125,132,138,146,149]$} \\
\hline Suspended particular matter & Not specified & {$[81,137]$} \\
\hline \multirow{5}{*}{ Water } & Not specified & [136] \\
\hline & Fresh water & {$[73,95,105,110,118,119,123,127,128,130,131,133,140]$} \\
\hline & Hot spring & [84] \\
\hline & Lagoon & [143] \\
\hline & Marine & {$[70,76,83,87,92,94,97,109]$} \\
\hline
\end{tabular}

\section{A: $T->C d$ mechanisms}

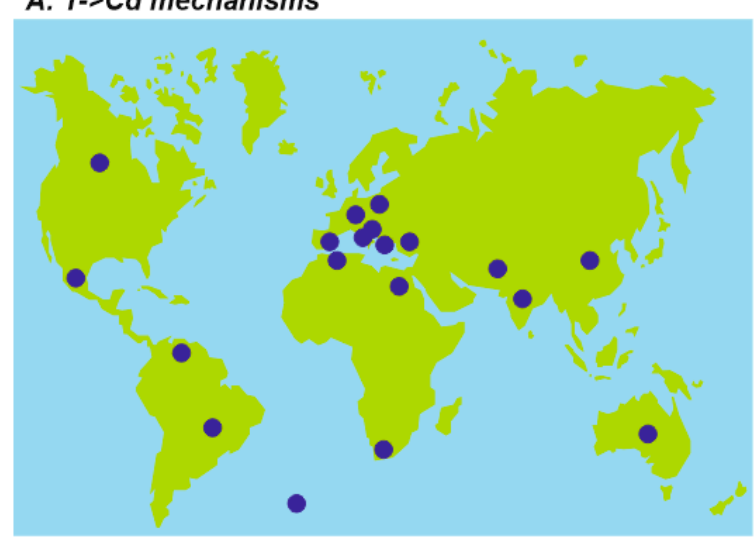

\section{B: $C d->T$ mechanisms}

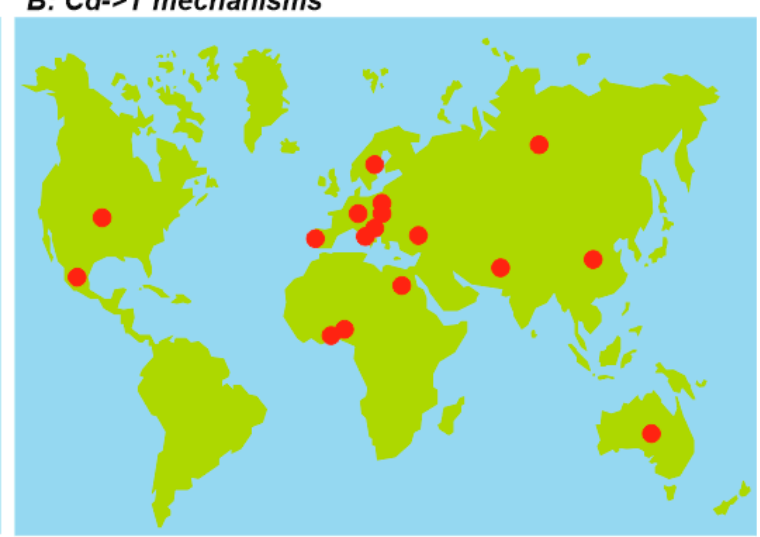

Figure 5. Examples of the contribution by tourism to $\mathrm{Cd}$ pollution (A) and Cd pollution creating risks to tourism (B). See Table 1 for data. 
These studies are commonly difficult to classify thematically as a consequence of the 'haphazard' character of the research, with respect to the cadmium-tourism relationships. Nonetheless, it seemed sensible to classify them on the basis of the analyzed environmental component (Table 2).

\section{Discussion: Tourism Environment and Lacking Research Topics}

As explained above, the tourism environment should be distinguished from other types of environment. The analysis of the considered studies implies that the relationships between $\mathrm{Cd}$ and tourism are (or can be) linked to this environment and its specific components (Figure 6) or rather, these relationships could be understood through the 'prism' of the tourism environment. Undoubtedly, these relationships resembled those established for densely populated areas, but some specific features should be mentioned explicitly. First, tourism is a factor of people concentration and fairly deep interacts with the environment (e.g., via an increased demand for local food), which increases human exposure to $\mathrm{Cd}$ pollution. Second, new sources of $\mathrm{Cd}$ pollution are linked to tourism, namely hotels. Third, tourism requires intensification of traffic and other activities that lead to $\mathrm{Cd}$ pollution; moreover, it appears that tourism creates new 'pools' of Cd accumulation (e.g., soils of artificial recreation areas).

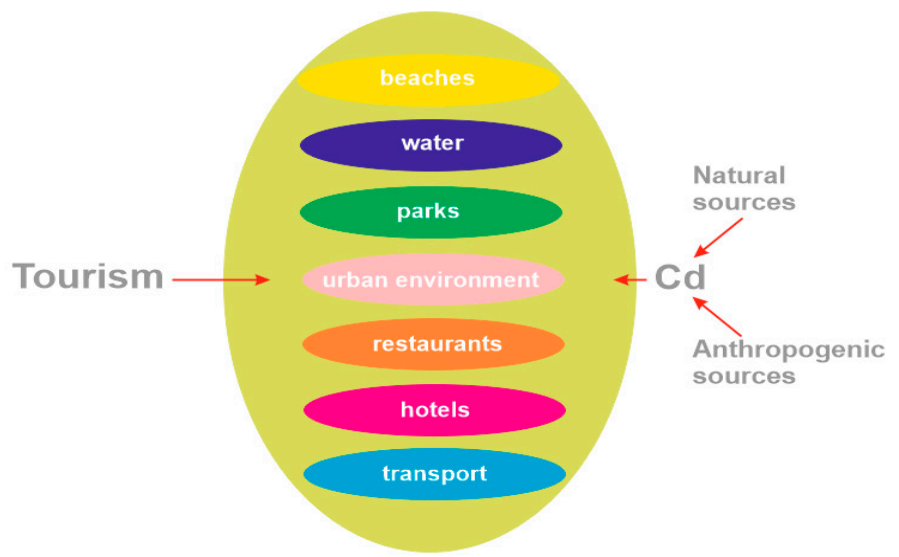

Figure 6. Schematic representation of the cadmium-tourism relationships through the components of the tourism environment (according to the literature reviewed here).

The above findings were intuitive and were limited to the relatively small group of case studies (Table 1); there is a significant lack in research on this topic. Three of them are worth discussing in the light of the available knowledge. The first research gap was linked to oversimplification of the cadmium-tourism relationships. Some (if not most) studies dealing with them offered quite simple interpretations regarding either $\mathrm{Cd}$ pollution or tourism. It was commonly stated, for instance, that a high Cd-content in coastal water or beach sediments is dangerous because such areas constitute direct tourism resources. In fact, it required detailed investigations to find out which particular mechanisms affect human health, e.g., how $\mathrm{Cd}$ affects health when a tourist swims in the polluted water or lies on a polluted beach. Scientifically correct approaches of this problem are not really common in the literature. An example of this was provided by Nilsen et al. [113], who were able to relate $\mathrm{Cd}$ accumulation in alligators to tourist exposure to this toxic metal. The explanations of tourism contribution to $\mathrm{Cd}$ pollution are often restricted to stating various activities like traffic as a source of $\mathrm{Cd}$. However, the knowledge of these activities needs to be detailed-for instance, is tourism seasonality important for Cd pollution? Usage of which hotel products lead to a high Cd-content in wastewater? A good example was the study by Ji et al. [96], who explained the importance of the Chinese Spring Festival for air pollution by Cd.

The second research gap was geographical. Insight into the Cd-tourism relationships would become essential when examples from the most important tourist destinations and the most polluted areas are considered. Good examples concern Egypt-the $\mathrm{Cd}$ in environments of the world-famous resorts along the Red Sea, including Sharm El-Sheikh and Hurghada, was discussed by Ahdy 
and Youssef [67] and Nour [114]. According to the World Tourism Organization [150], the ten most visited tourist destinations (at the country level) are France, Spain, the USA, China, Italy, Turkey, Mexico, Germany, Thailand, and the UK (totally, $>0.5$ bln international tourist arrivals per year). However, only China and, to a lesser degree Spain, the USA, and Turkey, could be proud of paying more or less adequate attention to the cadmium-tourism relationships on their territory (Table 1 , Figure 4). None of the considered studies dealt with France or the UK. Of course, this did not mean that there was no $\mathrm{Cd}$ in the tourism environments of these countries. In contrast, there was clear evidence of pollution increase/decrease, although examined without reference to tourism. Noack et al. [159] detected high and dangerous $\mathrm{Cd}$ concentrations in air, soil, and vegetables in Marseille (Southern France) and also demonstrated that subsequent factory closure led to a decrease in the level of air pollution. Strady et al. [160] discussed bioaccumulation of Cd in the Marennes-Oléron Bay, known as the largest oyster production site of France. In the UK, Goddard et al. [161] found a significant decrease in the Cd content in ambient air, since the beginning of the 2000s, and residential and industrial burning of wood and biomass had become the main source of this metal emission. Undoubtedly, all of these findings should be discussed in the light of tourism development.

The third research gap was linked to the necessity of serious investigation of such a mechanism as tourist exposure to $\mathrm{Cd}$, due to its concentration in tableware and canned food. Previous research (not linked to tourism) has demonstrated the importance of this issue [162-164]. Presumably, hotel spaces and food consumption in remote places pose risks to tourists. However, the significance of these risks and their geographical distribution are yet to be determined. This gap should be filled by future research.

\section{Conclusions}

The review of the literature on the cadmium-tourism relationships permitted us to draw five general conclusions that reflect the present state of the relevant knowledge. First, Cd occurrence and cycling in the tourism environment was proven to be a common phenomenon, and a significant amount of knowledge of $\mathrm{Cd}$ in tourism environment was obtained worldwide in the course of three decades, although through somewhat 'marginal' and locally-focused research. Second, Cd was associated with both common components of the tourism environment (air, soil, water, etc.) and its specific components (beaches, hotels, parks, etc.). Third, the contribution of tourism to $\mathrm{Cd}$ pollution and the danger of the latter to tourists seemed to be equally important topics to researchers. The relevant studies focused largely on evidence from China and Spain. Fourth, the reviewed literature focused on how tourism contributed to the $\mathrm{Cd}$ pollution in the Mediterranean and how risky $\mathrm{Cd}$ pollution was for tourism development in Central and Eastern Europe. The other regions were addressed with less attention or not addressed at all. Fifth, two principal research gaps were related to the insufficiently developed idea of what scientific knowledge should be obtained, as well as to geographical biases. Consequently, our current understanding of the cadmium-tourism relationships is unavoidably incomplete.

This literature review has evident implications for further research. It makes clear that the cadmium-tourism relationships constitute a really distinctive phenomenon that is worth analyzing for both fundamentally scientific and managerial purposes. Therefore, future research should be shifted to a higher level, i.e., studies should focus simultaneously on Cd pollution and tourism. Evidently, such studies need to be conducted in both popular tourist destinations and areas known for their high levels of $\mathrm{Cd}$ in the environment. Nonetheless, the already available knowledge reviewed in the present paper forms a firm ground for correct planning of future research projects.

Author Contributions: Conceptualization, A.V.M. and D.A.R.; methodology, D.A.R.; investigation, D.A.R. and V.A.E.; writing-original draft preparation, A.V.M. and D.A.R.; writing-review and editing, D.A.R. and A.J.v.L. All authors have read and agreed to the published version of the manuscript.

Funding: This research received no external funding. 
Acknowledgments: The authors gratefully thank the journal editors and the reviewers for their valuable recommendations and support.

Conflicts of Interest: The authors declare no conflict of interest.

\section{References}

1. Gössling, S.; Peeters, P. Assessing tourism's global environmental impact 1900-2050. J. Sustain. Tour. 2015, 23, 639-659. [CrossRef]

2. Ding, Y. Deformation monitoring method for wind erosion on humanities and tourism environment damage in scenic spots. Ekoloji 2019, 28, 2489-2494.

3. Han, J. Carrying capacity of low carbon tourism environment in coastal areas from the perspective of ecological efficiency. J. Coast. Res. 2018, 83, 199-203. [CrossRef]

4. Jeong, Y.; Kim, S.-K.; Yu, J.-G. Sustaining sporting destinations through improving tourists' mental and physical health in the tourism environment: The case of Korea. Int. J. Environ. Res. Public Health 2020, 17, 122. [CrossRef] [PubMed]

5. Tyrväinen, L.; Silvennoinen, H.; Hallikainen, V. Effect of the season and forest management on the visual quality of the nature-based tourism environment: A case from Finnish Lapland. Scand. J. For. Res. 2017, 32, 349-359. [CrossRef]

6. Yu, H. Evolution analysis of the coupling coordination degree between ecological tourism and tourism environment in Henan Province. Ekoloji 2019, 28, 1517-1522.

7. Jennings, S. Coastal tourism and shoreline management. Ann. Tour. Res. 2004, 31, 899-922. [CrossRef]

8. Duhamel, P.; Knafou, R. Tourism and coastline: Interests and limits about a relationship. Ann. De Géographie 2003, 629, 47-67. [CrossRef]

9. Beladi, H.; Chao, C.-C.; Hazari, B.R.; Laffargue, J.-P. Tourism and the environment. Resour. Energy Econ. 2009, 31, 39-49. [CrossRef]

10. Buckley, R. Tourism and environment. Annu. Rev. Environ. Resour. 2011, 36, 397-416. [CrossRef]

11. Butler, R.W. Tourism, Environment, and Sustainable Development. Environ. Conserv. 1991, 18, $201-209$. [CrossRef]

12. Butler, R.W. Tourism and the environment: A geographical perspective. Tour. Geogr. 2000, 2, 337-358. [CrossRef]

13. Butler, R. Sustainable tourism in sensitive environments: A Wolf in sheep's clothing? Sustainability 2018, 10, 1789. [CrossRef]

14. Cohen, E. The impact of tourism on the physical environment. Ann. Tour. Res. 1978, 5, 215-237. [CrossRef]

15. Davenport, J.; Davenport, J.L. The impact of tourism and personal leisure transport on coastal environments: A review. Estuar. Coast. Shelf Sci. 2006, 67, 280-292. [CrossRef]

16. Demerle, E.B.; Molozhavenko, V.L.; Popkova, A.A. Elemental management of the development of tourism business with the preservation of the environment. J. Environ. Manag. Tour. 2019, 10, 1259-1268.

17. Erize, F.J. The impact of tourism on the Antarctic environment. Environ. Int. 1987, 13, 133-136. [CrossRef]

18. Lai, Z.; Ge, D.; Xia, H.; Yue, Y.; Wang, Z. Coupling coordination between environment, economy and tourism: A case study of China. Plos One 2020, 15, e0228426. [CrossRef]

19. Miller, M.L.; Auyong, J. Coastal zone tourism. A potent force affecting environment and society. Mar. Policy 1991, 15, 75-99. [CrossRef]

20. Lee, J.W.; Brahmasrene, T. Tourism effects on the environment and economic sustainability of sub-Saharan Africa. Int. J. Sustain. Dev. World Ecol. 2016, 23, 221-232. [CrossRef]

21. Marsiglio, S. Economic growth and environment: Tourism as a trigger for green growth. Tour. Econ. 2015, 21, 183-204. [CrossRef]

22. Ruban, D.A.; Molchanova, T.K.; Yashalova, N.N. Three rising tourism directions and climate change: Conceptualizing new opportunities. e-Rev. Tour. Res. 2019, 16, 352-370.

23. Gössling, S.; Peeters, P. 'It does not harm the environment!' An analysis of industry discourses on tourism, air travel and the environment. J. Sustain. Tour. 2007, 15, 402-417. [CrossRef]

24. Koçak, E.; Ulucak, R.; Ulucak, Z.S. The impact of tourism developments on $\mathrm{CO}_{2}$ emissions: An advanced panel data estimation. Tour. Manag. Perspect. 2020, 33, 100611. [CrossRef] 
25. Luo, F.; Moyle, B.D.; Moyle, C.-L.J.; Zhong, Y.; Shi, S. Drivers of carbon emissions in China's tourism industry. J. Sustain. Tour. 2020, 28, 747-770. [CrossRef]

26. Russo, M.A.; Relvas, H.; Gama, C.; Lopes, M.; Borrego, C.; Rodrigues, V.; Robaina, M.; Madaleno, M.; Carneiro, M.J.; Eusébio, C. Estimating emissions from tourism activities. Atmos. Environ. 2020, 220, 117048. [CrossRef]

27. Tang, M.; Ge, S. Accounting for carbon emissions associated with tourism-related consumption. Tour. Econ. 2018, 24, 510-525. [CrossRef]

28. Wang, M.-C.; Wang, C.-S. Tourism, the environment, and energy policies. Tour. Econ. 2018, 24, 821-838. [CrossRef]

29. Zhang, J.; Zhang, Y. Carbon tax, tourism $\mathrm{CO}_{2}$ emissions and economic welfare. Ann. Tour. Res. 2018, 69, 18-30. [CrossRef]

30. Alloway, B.J. Sources of Heavy Metals and Metalloids in Soils. In Heavy Metals in Soils: Trace Metals and Metalloids in Soils and Their Bioavailability; Alloway, B.J., Ed.; Springer: Dordrecht, The Netherlands, 2013; pp. 11-50.

31. Ciarkowska, K. Assessment of heavy metal pollution risks and enzyme activity of meadow soils in urban area under tourism load: A case study from Zakopane (Poland). Environ. Sci. Pollut. Res. 2018, 25, 13709-13718. [CrossRef]

32. Kellner, A.W.A. Heavy metals partitioning in the Rodrigo de Freitas lagoon; larvicidal potential of a new essential oil against Aedes aegypti; and the socioeconomic impact of tourism due to wild dolphins provisioning. An. Da Acad. Bras. De Cienc. 2013, 85, 1215-1216. [CrossRef] [PubMed]

33. Kim, S.-M.; Choi, Y. Mapping heavy metal concentrations in Beach Sands using GIS and Portable XRF data. J. Mar. Sci. Eng. 2019, 7, 42. [CrossRef]

34. Mansour, A.M.; Askalany, M.S.; Madkour, H.A.; Assran, B.B. Assessment and comparison of heavy-metal concentrations in marine sediments in view of tourism activities in Hurghada area, northern Red Sea, Egypt. Egypt. J. Aquat. Res. 2013, 39, 91-103. [CrossRef]

35. Zakaly, H.M.; Uosif, M.A.; Madkour, H.; Tammam, M.; Issa, S.; Elsaman, R.; El-Taher, A. Assessment of natural radionuclides and heavy metal concentrations in marine sediments in view of tourism activities in Hurghada city, northern Red Sea, Egypt. J. Phys. Sci. 2019, 30, 21-47. [CrossRef]

36. Billah, M.M.; Kokushi, E.; Uno, S. Distribution, Geochemical Speciation, and Bioavailable Potencies of Cadmium, Copper, Lead, and Zinc in Sediments from Urban Coastal Environment in Osaka Bay, Japan. Water Air Soil Pollut. 2019, 230, 157. [CrossRef]

37. Campbell, P.G.C. Cadmium-A priority pollutant. Environ. Chem. 2006, 3, 387-388. [CrossRef]

38. Chuanwei, Z.; Hanjie, W.; Yuxu, Z.; Yizhang, L.; Rongfei, W. Isotopic geochemistry of cadmium: A review. Acta Geol. Sin. 2015, 89, 2048-2057. [CrossRef]

39. Elinder, C.G. Cadmium as an environmental hazard. Iarc Sci. Publ. 1992, 118, 123-132.

40. Fatima, G.; Raza, A.M.; Hadi, N.; Nigam, N.; Mahdi, A.A. Cadmium in Human Diseases: It's More than Just a Mere Metal. Indian J. Clin. Biochem. 2019, 34, 371-378. [CrossRef]

41. Flick, D.F.; Kraybill, H.F.; Dimitroff, J.M. Toxic effects of cadmium: A review. Environ. Res. 1971, 4, 71-85. [CrossRef]

42. Gardiner, J. The chemistry of cadmium in natural water-II. The adsorption of cadmium on river muds and naturally occurring solids. Water Res. 1974, 8, 157-164. [CrossRef]

43. Hayat, M.T.; Nauman, M.; Nazir, N.; Ali, S.; Bangash, N. Environmental Hazards of Cadmium. Past, Present, and Future. In Cadmium Toxicity and Tolererance in Plants:From Physiology to Remediatiation; Academic Press: Cambridge, MA, USA, 2019; pp. 163-183.

44. Jensen, A.; Bro-Rasmussen, F. Environmental cadmium in Europe. Rev. Environ. Contam. Toxicol. 1992, 125, 101-181. [PubMed]

45. Kasuya, M.; Teranishi, H.; Aoshima, K.; Katoh, T.; Horiguchi, H.; Morikawa, Y.; Nishijo, M.; Iwata, K. Water pollution by cadmium and the onset of Itai-itai disease. Water Sci. Technol. 1992, 26, 149-156. [CrossRef]

46. Kim, N.D.; Fergusson, J.E. The concentrations, distribution and sources of cadmium, copper, lead and zinc in the atmosphere of an urban environment. Sci. Total Environ. 1994, 144, 179-189. [CrossRef]

47. Komarnicki, G.J.K. Lead and cadmium in indoor air and the urban environment. Environ. Pollut. 2005, 136, 47-61. [CrossRef] 
48. Kubier, A.; Wilkin, R.T.; Pichler, T. Cadmium in soils and groundwater: A review. Appl. Geochem. 2019, 108, 104388. [CrossRef]

49. Lu, F.; Yan, H.; Dai, C.; Xu, W.; Gu, F.; Zhang, F.; Li, T.; Xian, J.; He, X.; Yu, Y. The systematic exploration of cadmium-accumulation characteristics of maize kernel in acidic soil with different pollution levels in China. Sci. Total Environ. 2020, 729, 138972.

50. Niño-Savala, A.G.; Zhuang, Z.; Ma, X.; Fangmeier, A.; Li, H.; Tang, A.; Liu, X. Cadmium pollution from phosphate fertilizers in arable soils and crops: An overview. Front. Agric. Sci. Eng. 2019, 6, 419-430. [CrossRef]

51. Pan, J.; Plant, J.A.; Voulvoulis, N.; Oates, C.J.; Ihlenfeld, C. Cadmium levels in Europe: Implications for human health. Environ. Geochem. Health 2010, 32, 1-12. [CrossRef]

52. Pastorino, P.; Prearo, M.; Bertoli, M.; Abete, M.C.; Dondo, A.; Salvi, G.; Zaccaroni, A.; Elia, A.C.; Pizzul, E. Accumulation of $\mathrm{As}, \mathrm{Cd}, \mathrm{Pb}$, and $\mathrm{Zn}$ in sediment, chironomids and fish from a high-mountain lake: First insights from the Carnic Alps. Sci. Total Environ. 2020, 729, 139007. [CrossRef]

53. Qin, S.; Liu, H.; Nie, Z.; Rengel, Z.; Gao, W.; Li, C.; Zhao, P. Toxicity of cadmium and its competition with mineral nutrients for uptake by plants: A review. Pedosphere 2020, 30, 168-180. [CrossRef]

54. Sanità Di Toppi, L.; Gabbrielli, R. Response to cadmium in higher plants. Environ. Exp. Bot. 1999, 41, $105-130$. [CrossRef]

55. Satarug, S.; Garrett, S.H.; Sens, M.A.; Sens, D.A. Cadmium, environmental exposure, and health outcomes. Environ. Health Perspect. 2010, 118, 182-190. [CrossRef]

56. Schaefer, H.R.; Dennis, S.; Fitzpatrick, S. Cadmium: Mitigation strategies to reduce dietary exposure. J. Food Sci. 2020, 85, 260-267. [CrossRef]

57. Smolders, E.; Mertens, J. Cadmium. In Heavy Metals in Soils: Trace Metals and Metalloids in Soils and Their Bioavailability; Alloway, B.J., Ed.; Springer: Dordrecht, The Netherlands, 2013; pp. 283-311.

58. Warren, L.J. Contamination of sediments by lead, zinc and cadmium: A review. Environ. Pollut. Ser. B Chem. Phys. 1981, 2, 401-436. [CrossRef]

59. Zhang, H.; Reynolds, M. Cadmium exposure in living organisms: A short review. Sci. Total Environ. 2019, 678, 761-767. [CrossRef]

60. Fernandez, K.V. Critically reviewing literature: A tutorial for new researchers. Australas. Mark. J. 2019, 27, 187-196. [CrossRef]

61. Koons, G.L.; Schenke-Layland, K.; Mikos, A.G. Why, When, Who, What, How, and Where for Trainees Writing Literature Review Articles. Ann. Biomed. Eng. 2019, 47, 2334-2340. [CrossRef]

62. Pati, D.; Lorusso, L.N. How to Write a Systematic Review of the Literature. Health Environ. Res. Des. J. 2018, 11, 15-30. [CrossRef]

63. Rewhorn, S. Writing your successful literature review. J. Geogr. High. Educ. 2018, 42, 143-147. [CrossRef]

64. Snyder, H. Literature review as a research methodology: An overview and guidelines. J. Bus. Res. 2019, 104, 333-339. [CrossRef]

65. Sovacool, B.K.; Axsen, J.; Sorrell, S. Promoting novelty, rigor, and style in energy social science: Towards codes of practice for appropriate methods and research design. Energy Res. Soc. Sci. 2018, 45, $12-42$. [CrossRef]

66. Wee, B.V.; Banister, D. How to Write a Literature Review Paper? Transp. Rev. 2016, 36, 278-288. [CrossRef]

67. Ahdy, H.H.H.; Youssef, D.H. Fractionation analysis of some heavy metals in sediments of the north-western part of the Red Sea, Egypt. Chem. Ecol. 2011, 27, 427-443. [CrossRef]

68. Akcay, N.; Batan, N.; Cinar, Y. Investigate of atmospheric arsenic, cadmium, chromium, lead, and mercury levels in moss species found around Zilkale, by EDXRF Spectrometry. Aip Conf. Proc. 2016, 1726, 020124.

69. Alomary, A.A.; Belhadj, S. Determination of heavy metals (Cd, Cr, Cu, Fe, Ni, Pb, Zn) by ICP-OES and their speciation in Algerian Mediterranean Sea sediments after a five-stage sequential extraction procedure. Environ. Monit. Assess. 2007, 135, 265-280. [CrossRef]

70. Alonso Castillo, M.L.; Sánchez Trujillo, I.; Vereda Alonso, E.; García de Torres, A.; Cano Pavón, J.M. Bioavailability of heavy metals in water and sediments from a typical Mediterranean Bay (Málaga Bay, Region of Andalucía, Southern Spain). Mar. Pollut. Bull. 2013, 76, 427-434. [CrossRef]

71. Anhichem, M.; Dellal, M.; Chfiri, R.; Yahyaoui, A.; Benbrahim, S. Étude de la qualité des eaux et des sédiments de la baie de Dakhla au Maroc. Qualité physico-chimique et contamination métallique. Bull. Soc. Zool. Fr. 2017, 142, 185-202. 
72. Baktybaeva, Z.B.; Suleymanov, R.A.; Yamalov, S.M.; Kulagin, A.A.; Valeev, T.K.; Rakhmatullin, N.R. Evaluation of the content and migration of heavy metals in components of river ecosystems' of mining territories of the Republic of Bashkortostan. Gig. Sanit. 2016, 95, 822-827. [CrossRef]

73. Bencko, V. Does surface water treatment need special measures in the Czech Republic. In Management of Intentional and Accidental Water Pollution; Springer: Dordrecht, The Netherlands, 2006; pp. 151-165, NATO Security through Science Series C: Environmental Security.

74. Bharagava, R.N.; Saxena, G.; Chowdhary, P. Constructed Wetlands: An Emerging Phytotechnology for Degradation and Detoxification of Industrial Wastewaters. In Environmental Pollutants and Their Bioremediation Approaches; CRC Press: Boca Raton, FL, USA, 2017; pp. 397-426.

75. Bhumibhamorn, P.; Visuthismajarn, P. A model for environmentally-friendly food tourism in Ban Koh Klang, Khlong Prasong Sub-District, Mueang District, Krabi, Thailand. Afr. J. Hosp. Tour. Leis. 2019, 8, 10.

76. Bohari, R.; Palutturi, S. Analysis of heavy metal distribution and content in coastal area of Makassar, Indonesia. Indian J. Public Health Res. Dev. 2018, 9, 210-213. [CrossRef]

77. Böhlandt, A.; Schierl, R.; Diemer, J.; Koch, C.; Bolte, G.; Kiranoglu, M.; Fromme, H.; Nowak, D. High concentrations of cadmium, cerium and lanthanum in indoor air due to environmental tobacco smoke. Sci. Total Environ. 2012, 414, 738-741. [CrossRef] [PubMed]

78. Bolte, G.; Heitmann, D.; Kiranoglu, M.; Schierl, R.; Diemer, J.; Koerner, W.; Fromme, H. Exposure to environmental tobacco smoke in German restaurants, pubs and discotheques. J. Expo. Sci. Environ. Epidemiol. 2008, 18, 262-271. [CrossRef] [PubMed]

79. Darmody, R.G.; Marlin, J.C.; Talbott, J.; Green, R.A.; Brewer, E.F.; Stohr, C. Dredged Illinois River Sediments: Plant Growth and Metal Uptake. J. Environ. Qual. 2004, 33, 458-464. [CrossRef]

80. De Roma, A.; Esposito, M.; Chiaravalle, E.; Miedico, O.; De Filippis, S.P.; Brambilla, G. Occurrence of cadmium, lead, mercury, and arsenic in prepared meals in Italy: Potential relevance for intake assessment. J. Food Compos. Anal. 2017, 63, 28-33. [CrossRef]

81. Demirak, A.; Yilmaz, H.A.; Keskin, F.; Sahin, Y.; Akpolat, O. Investigation of heavy metal content in the suspended particulate matter and sediments of inner Gokova Bay and creeks. Environ. Monit. Assess. 2012, 184, 7113-7124. [CrossRef] [PubMed]

82. Eddaoudi, R.; Chafik, A.; Cheggour, A.; Moukrim, A. Contribution to reassess the health of Agadir Bay after the installation of the wastewater treatment plant: Evaluation of metallic contamination. J. Mater. Environ. Sci. 2014, 5, 2278-2283.

83. El Ati-Hellal, M.; Hedhili, A.; Hellal, F.; Boujlel, K.; Dachraoui, M.; Bousnina, M.; Ghorbel, H.; Ndhif, M. Lead and cadmium concentrations in seawater and algae of the Tunisian coast. Arch. Inst. Pasteur Tunis 2005, 82, 75-82.

84. Fan, G.; Zhai, D.; Zou, D. Highly sensitive electrochemical determination of cadmium (II) in environmental water based on the electrodeposited bismuth nanoparticles. Int. J. Electrochem. Sci. 2016, 11, 4362-4370. [CrossRef]

85. Fitzmorris, K.B.; Lima, I.M.; Marshall, W.E.; Reimers, R.S. Anion and cation removal from solution using activated carbons from municipal sludge and poultry manure. J. Residuals Sci. Technol. 2006, 3, 161-167.

86. Frimpong, S.K.; Koranteng, S.S. Levels and human health risk assessment of heavy metals in surface soil of public parks in Southern Ghana. Environ. Monit. Assess. 2019, 191, 588. [CrossRef] [PubMed]

87. García, E.M.; Cruz-Motta, J.J.; Farina, O.; Bastidas, C. Anthropogenic influences on heavy metals across marine habitats in the western coast of Venezuela. Cont. Shelf Res. 2008, 28, 2757-2766. [CrossRef]

88. Geghamyan, S.; Pavlicková, K. The mining versus the recreation-Study from Armenia. In Proceedings of the Public Recreation and Landscape Protection-With Nature Hand in Hand? Křtiny, Czech Republic, 2-4 May 2018; pp. 353-356.

89. Gidarakos, E.; Havas, G.; Ntzamilis, P. Municipal solid waste composition determination supporting the integrated solid waste management system in the island of Crete. Waste Manag. 2006, 26, 668-679. [CrossRef] [PubMed]

90. Gladyshev, M.I.; Gribovskaya, I.V.; Moskvicheva, A.V.; Muchkina, E.Y.; Chuprov, S.M.; Ivanova, E.A. Content of metals in compartments of ecosystem of a Siberian pond. Arch. Environ. Contam. Toxicol. 2001, 41, 157-162. 
91. González, I.; Águila, E.; Galán, E. Partitioning, bioavailability and origin of heavy metals from the Nador Lagoon sediments (Morocco) as a basis for their management. Environ. Geol. 2007, 52, 1581-1593. [CrossRef]

92. Hassan, E.S.; Banat, I.M.; El-Shahawi, M.S.; Abu-Hilal, A.H. Bacterial, nutrients and heavy metal ions pollution assessment along the eastern coastal area of the United Arab Emirates. J. Aquat. Ecosyst. Stress Recovery 1996, 5, 73-81. [CrossRef]

93. Ivankovic, D.; Erk, M.; Župan, I.; Culin, J.; Dragun, Z.; Bacic, N.; Cindric, A.-M. Trace Metals in Noah's Ark Shells (Arca noae Linnaeus, 1758): Impact of Tourist Season and Human Health Risk. Arch. Environ. Contam. Toxicol. 2016, 71, 394-404. [CrossRef]

94. Jahan, S.; Strezov, V. Water quality assessment of Australian ports using water quality evaluation indices. Plos One 2017, 12, e0189284. [CrossRef]

95. Jeszke, M.; Kubiak-Limu, K.; Zyniewicz, H. Evaluation of the current state of pollution of selected natural water resources with cadmium and lead. Rocz. Panstw. Zakl. Hig. 1994, 45, 321-326.

96. Ji, D.; Cui, Y.; Li, L.; He, J.; Wang, L.; Zhang, H.; Wang, W.; Zhou, L.; Maenhaut, W.; Wen, T. Characterization and source identification of fine particulate matter in urban Beijing during the 2015 Spring Festival. Sci. Total Environ. 2018, 628, 430-440. [CrossRef]

97. Jonathan, M.P.; Roy, P.D.; Thangadurai, N.; Srinivasalu, S.; Rodríguez-Espinosa, P.F.; Sarkar, S.K.; Lakshumanan, C.; Navarrete-López, M.; Muñoz-Sevilla, N.P. Metal concentrations in water and sediments from tourist beaches of Acapulco, Mexico. Mar. Pollut. Bull. 2011, 62, 845-850. [CrossRef] [PubMed]

98. Joy, A.; Mathew, J.; Mathew, A.; Gopinath, A. Spatial variation of trace element concentration and contamination assessment in the coral reef sediments of Lakshadweep Archipelago, Indian Ocean. Mar. Pollut. Bull. 2019, 146, 106-116. [CrossRef] [PubMed]

99. Joy, A.; Anoop, P.P.; Rajesh, R.; Mathew, A.; Gopinath, A. Spatial Distribution and Contamination Assessment of Trace Metals in the Coral Reef Sediments of Kavaratti Island in Lakshadweep Archipelago, Indian Ocean. Soil Sediment Contam. 2020, 29, 209-231. [CrossRef]

100. Kawecka-Radomska, M.; Tomczynska-Mleko, M.; Kaminska, A.; Wesolowska-Trojanowska, M.; Kwiatkowski, C.; Solowiej, B.; Mleko, S. Biochemical changes in the recreational areas soil caused by the intensity of use. Environ. Earth Sci. 2016, 75, 1-14. [CrossRef]

101. LaValle, P.D.; Brooks, A.; Lakhan, V.C. Zebra mussel wastes and concentrations of heavy metals on shipwrecks in western Lake Erie. J. Great Lakes Res. 1999, 25, 330-338. [CrossRef]

102. Li, H.; Shi, A.; Zhang, X. Particle size distribution and characteristics of heavy metals in road-deposited sediments from Beijing Olympic Park. J. Environ. Sci. 2015, 32, 228-237. [CrossRef]

103. Li, Y.; Li, H.-G.; Liu, F.-C. Pollution in the urban soils of Lianyungang, China, evaluated using a pollution index, mobility of heavy metals, and enzymatic activities. Environ. Monit. Assess. 2017, 189, 34. [CrossRef]

104. Liu, X.; Jiang, Y.; Gao, J.; Yin, H.; Cai, Y. Pollution characteristics of heavy metals and the risk assessment for the surface sediments from Lake Chaohu and its main tributary rivers. Hupo Kexue/J. Lake Sci. 2016, 28, 502-512.

105. Liu, M.; Xu, Y.; Nawab, J.; Rahman, Z.; Khan, S.; Idress, M.; Uddin, Z.; Ali, A.; Ahmad, R.; Khan, S.A. Contamination features, geo-accumulation, enrichments and human health risks of toxic heavy metal(loids) from fish consumption collected along Swat river, Pakistan. Environ. Technol. Innov. 2020, 17, 100554. [CrossRef]

106. Macdonald, R.W.; Harner, T.; Fyfe, J. Recent climate change in the Arctic and its impact on contaminant pathways and interpretation of temporal trend data. Sci. Total Environ. 2005, 342, 5-86. [CrossRef]

107. Macleod, C.; Coughanowr, C. Heavy metal pollution in the Derwent estuary: History, science and management. Reg. Stud. Mar. Sci. 2019, 32, 100866. [CrossRef]

108. Mali, M.; Dell'Anna, M.M.; Mastrorilli, P.; Damiani, L.; Piccinni, A.F. Assessment and source identification of pollution risk for touristic ports: Heavy metals and polycyclic aromatic hydrocarbons in sediments of 4 marinas of the Apulia region. Mar. Pollut. Bull. 2017, 114, 768-777. [CrossRef] [PubMed]

109. Martínez-Soto, M.C.; Tovar-Sánchez, A.; Sánchez-Quiles, D.; Rodellas, V.; Garcia-Orellana, J.; Basterretxea, G. Seasonal variation and sources of dissolved trace metals in Maó Harbour, Minorca Island. Sci. Total Environ. 2016, 565, 191-199. [CrossRef] [PubMed]

110. Mikac, I.; Fiket, Ž.; Terzic, S.; Barešic, J.; Mikac, N.; Ahel, M. Chemical indicators of anthropogenic impacts in sediments of the pristine karst lakes. Chemosphere 2011, 84, 1140-1149. [CrossRef] 
111. Miskowiec, P.; Laptas, A.; Zieba, K. Soil pollution with heavy metals in industrial and agricultural areas: A case study of Olkusz District. J. Elem. 2015, 20, 353-362. [CrossRef]

112. Nikolic, D.; Skoric, S.; Lenhardt, M.; Hegediš, A.; Krpo-Cetkovic, J. Risk assessment of using fish from different types of reservoirs as human food-A study on European perch (Perca fluviatilis). Environ. Pollut. 2020, 257, 113586. [CrossRef]

113. Nilsen, F.M.; Bowden, J.A.; Rainwater, T.R.; Brunell, A.M.; Kassim, B.L.; Wilkinson, P.M.; Guillette, L.J., Jr.; Long, S.E.; Schock, T.B. Examining toxic trace element exposure in American alligators. Environ. Int. 2019, 128, 324-334. [CrossRef]

114. Nour, H.E.S. Distribution, ecological risk, and source analysis of heavy metals in recent beach sediments of Sharm El-Sheikh, Egypt. Environ. Monit. Assess. 2019, 191, 546. [CrossRef]

115. Paixão, J.F.; De Oliveira, O.M.C.; Dominguez, J.M.L.; Almeida, E.D.S.; Correia Carvalho, G.; Magalhães, W.F. Integrated assessment of mangrove sediments in the Camamu Bay (Bahia, Brazil). Ecotoxicol. Environ. Saf. 2011, 74, 403-415. [CrossRef]

116. Peña-Fernández, A.; González-Muñoz, M.J.; Lobo-Bedmar, M.C. Establishing the importance of human health risk assessment for metals and metalloids in urban environments. Environ. Int. 2014, 72, 176-185. [CrossRef]

117. Peng, C.; Cai, Y.; Wang, T.; Xiao, R.; Chen, W. Regional probabilistic risk assessment of heavy metals in different environmental media and land uses: An urbanization-affected drinking water supply area. Sci. Rep. 2016, 6, 37084. [CrossRef] [PubMed]

118. Persson, G.; Olsson, H.; Wiederholm, T.; Willen, E. Lake Vattern, Sweden: A 20-year perspective. Ambio 1989, 18, 208-215.

119. Pip, E. Surface water quality in Manitoba with respect to six chemical parameters, water body and sediment type and land use. Aquat. Ecosyst. Health Manag. 2005, 8, 195-207. [CrossRef]

120. Pourabadehei, M.; Mulligan, C.N. Selection of an appropriate management strategy for contaminated sediment: A case study at a shallow contaminated harbour in Quebec, Canada. Environ. Pollut. 2016, 219, 846-857. [CrossRef] [PubMed]

121. Prego, R.; Cobelo-García, A. Twentieth century overview of heavy metals in the Galician Rias (NW Iberian Peninsula). Environ. Pollut. 2003, 121, 425-452. [CrossRef]

122. Pruekparichart, M.; Hattayanon, M.; Isaramalai, S.-A.; Techato, K. Economic incentives and social influences to separate used dry batteries at source: A lesson learned from the tourist resort of Hat-Yai, Songkhla Province, Thailand. Afr. J. Hosp. Tour. Leis. 2019, 8, 11.

123. Rajan, S.; Firdaus, N.N.M.; Appukutty, M.; Ramasamy, K. Effects of climate changes on dissolved heavy metal concentrations among recreational park tributaries in Pahang, Malaysia. Biomed. Res. 2012, 23, $23-30$.

124. Ramessur, R.T.; Parry, S.J.; Jarvis, K.E. Characterization of some trace metals from the Export Processing Zone and a coastal tourist area in Mauritius using inductively coupled plasma mass spectrometry. Environ. Int. 1998, 24, 773-781. [CrossRef]

125. Rybakov, D.S. Heavy metals and metalloids in soils and macromycetes from the accumulated environmental damage zone in Petrozavodsk, Republic of Karelia. Lect. Notes Earth Syst. Sci. 2020, 345-362.

126. Rzetala, M.A.; Rzetala, M.; Jankowski, G. The Ecological Status of Water Bodies in the Ostrava Urban and Industrial Region and Their Potential New Use in Tourism and Recreation. In Proceedings of the International Multidisciplinary Scientific GeoConference Surveying Geology and Mining Ecology Management, SGEM Albena, Bulgaria, 18-24 June 2015; Volume 1, pp. 609-616.

127. Rzymski, P.; Niedzielski, P.; Klimaszyk, P.; Poniedzialek, B. Bioaccumulation of selected metals in bivalves (Unionidae) and Phragmites australis inhabiting a municipal water reservoir. Environ. Monit. Assess. 2014, 186, 3199-3212. [CrossRef]

128. Salvadó, V.; Quintana, X.D.; Hidalgo, M. Monitoring of nutrients, pesticides, and metals in waters, sediments, and fish of a wetland. Arch. Environ. Contam. Toxicol. 2006, 51, 377-386. [CrossRef] [PubMed]

129. Saxena, D.K.; Saiful-Arfeen, M. Active biomonitoring of atmospheric metal deposition by Bryum species around Almora, Nainital and Pithoragarh of Kumaon Hills India. Nat. Environ. Pollut. Technol. 2010, 9, 1-12.

130. Shafiq, H.B.; Ajaz, M.; Rasool, S.A. Bacterial and toxic pollutants in lakes of river Indus. Pak. J. Bot. 2011, 43, 1765-1772. 
131. Shakir, H.A.; Qazi, J.I.; Chaudhry, A.S. Monitoring the impact of urban effluents on mineral contents of water and sediments of four sites of the river Ravi, Lahore. Environ. Monit. Assess. 2013, 185, 9705-9715. [CrossRef] [PubMed]

132. Shi, G.-T.; Chen, Z.-L.; Xu, S.-Y.; Wang, L.; Zhang, J.; Li, H.-W.; Li, L.-N. Characteristics of heavy metal pollution in soil and dust of urban parks in Shanghai. Huanjing Kexue/Environ. Sci. 2007, 28, 238-242.

133. Shine, J.P.; Ryan, D.K.; Ford, T.E. Annual cycle of heavy metals in a yropical lake-Lake Chapala, Mexico. J. Environ. Sci. Health A Hazard. Subst. Environ. Eng. 1998, 33, 23-43. [CrossRef]

134. Shparyk, Y.S.; Parpan, V.I. Heavy metal pollution and forest health in the Ukrainian Carpathians. Environ. Pollut. 2004, 130, 55-63. [CrossRef]

135. Song, Y.; Yu, K.; Zhao, J.; Feng, Y.; Shi, Q.; Zhang, H.; Ayoko, G.A.; Frost, R.L. Past 140-year environmental record in the northern South China Sea: Evidence from coral skeletal trace metal variations. Environ. Pollut. 2014, 185, 97-106. [CrossRef]

136. Sun, F.; Ge, D.; Fan, G. One-Pot synthesis of a graphene- $\mathrm{TiO}_{2}$ anocomposite for the sensitive determination of Cadmium(II) in environmental water. Int. J. Electrochem. Sci. 2017, 12, 7377-7385. [CrossRef]

137. Sylaios, G.; Kamidis, N.; Stamatis, N. Assessment of trace metals contamination in the suspended natter and sediments of a semi-enclosed Mediterranean gulf. Soil Sediment Contam. 2012, 21, 673-700. [CrossRef]

138. Timofeev, I.; Kosheleva, N.; Kasimov, N. Health risk assessment based on the contents of potentially toxic elements in urban soils of Darkhan, Mongolia. J. Environ. Manag. 2019, 242, 279-289. [CrossRef] [PubMed]

139. Torres, P.; Rodrigues, A.; Prestes, A.C.L.; Neto, A.I.; Álvaro, N.; Martins, G.M. The Azorean edible abalone Haliotis tuberculata, an alternative heavy metal-free marine resource? Chemosphere 2020, 242, 125177. [CrossRef]

140. Umunnakwe John Bosco, E.; Nnaji, A.O.; Ejimmaduekwu, P.I. Preliminary assessment of some physicochemical parameters during dredging of Nworie River, Owerri. Pak. J. Nutr. 2011, 10, 269-273.

141. Valdelamar-Villegas, J.; Olivero-Verbel, J. Bioecological aspects and heavy metal contamination of the mollusk Donax denticulatus in the Colombian Caribbean Coastline. Bull. Environ. Contam. Toxicol. 2018, 100, $234-239$. [CrossRef] [PubMed]

142. Varkouhi, S. Biogeochemical evaluation of trace elements in fish liver case study: Khorramabad River Basin, Lorestan, Iran. Iran. J. Sci. Technol. Trans. A Sci. 2007, 31, 53-61.

143. Veiga, K.; Pedro, C.A.; Santos, M.S.S.; Ferreira, S.M.F.; Gonçalves, S.C. The Bivalve cerastoderma edule as a Bioindicator for Metals Contamination in Coastal Lagoons. In Coastal Lagoons: Geology, Characteristics and Diversity Coast; Nova Science Publisher's, Inc.: Hauppauge, NY, USA, 2016; pp. 45-64.

144. Vetrimurugan, E.; Jonathan, M.P.; Roy, P.D.; Shruti, V.C.; Ndwandwe, O.M. Bioavailable metals in tourist beaches of Richards Bay, Kwazulu-Natal, South Africa. Mar. Pollut. Bull. 2016, 105, 430-436. [CrossRef]

145. Vetrimurugan, E.; Shruti, V.C.; Jonathan, M.P.; Roy, P.D.; Kunene, N.W.; Villegas, L.E.C. Metal concentration in the tourist beaches of South Durban: An industrial hub of South Africa. Mar. Pollut. Bull. 2017, 117, 538-546. [CrossRef]

146. Wang, G.; Zeng, C.; Zhang, F.; Zhang, Y.; Scott, C.A.; Yan, X. Traffic-related trace elements in soils along six highway segments on the Tibetan Plateau: Influence factors and spatial variation. Sci. Total Environ. 2017, 581, 811-821. [CrossRef]

147. Wei, X.; Gao, B.; Wang, P.; Zhou, H.; Lu, J. Pollution characteristics and health risk assessment of heavy metals in street dusts from different functional areas in Beijing, China. Ecotoxicol. Environ. Saf. 2015, 112, 186-192. [CrossRef]

148. Yalcin, M.G.; Ilhan, S. Multivariate analyses to determine the origin of potentially harmful heavy metals in beach and dune sediments from Kizkalesi coast (Mersin), Turkey. Bull. Environ. Contam. Toxicol. 2008, 81, 57-68. [CrossRef]

149. Yang, H.; Wang, M.; Dong, X.Y. Assessing human carcinogenic risk of heavy metal exposure in a tourist area. Adv. Mater. Res. 2013, 726, 846-849. [CrossRef]

150. UNWTO. International Tourism Highlights, 2019 ed.; UNWTO: Madrid, Spain, 2019; 23p.

151. Doxiadis, T.; Liveri, D. Symbiosis: Integrating tourism and Mediterranean landscapes. J. Place Manag. Dev. 2013, 6, 240-255. [CrossRef]

152. Dritsakis, N. Tourism development and economic growth in seven Mediterranean countries: A panel data approach. Tour. Econ. 2012, 18, 801-816. [CrossRef]

153. Lloret, J. Human health benefits supplied by Mediterranean marine biodiversity. Mar. Pollut. Bull. 2010, 60, 1640-1646. [CrossRef] [PubMed] 
154. Niavis, S.; Tsiotas, D. Assessing the tourism performance of the Mediterranean coastal destinations: A combined efficiency and effectiveness approach. J. Destin. Mark. Manag. 2019, 14, 100379. [CrossRef]

155. Pulido-Fernandez, J.I.; Cardenas-Garcia, P.J.; Sanchez-Rivero, M. Tourism competitiveness in Mediterranean countries: Identification of determining attributes. Actual Probl. Econ. 2014, 156, 132-142.

156. Tovar-Sánchez, A.; Sánchez-Quiles, D.; Rodríguez-Romero, A. Massive coastal tourism influx to the Mediterranean Sea: The environmental risk of sunscreens. Sci. Total Environ. 2019, 656, 316-321. [CrossRef]

157. Meier, L.; Aytekin, E.A. Transformed landscapes and a transnational identity of class: Narratives on (post-) industrial landscapes in Europe. Int. Sociol. 2019, 34, 99-116. [CrossRef]

158. Stuczynski, T.; Siebielec, G.; Korzeniowska-Puculek, R.; Koza, P.; Pudelko, R.; Lopatka, A.; Kowalik, M. Geographical location and key sensitivity issues of post-industrial regions in Europe. Environ. Monit. Assess. 2009, 151, 77-91. [CrossRef]

159. Noack, Y.; Lefloch, M.; Robin, D. Environmental impact of a cadmium atmospheric pollution at Marseille (South France). J. De Physique. IV JP 2003, 107, 961-964. [CrossRef]

160. Strady, E.; Blanc, G.; Baudrimont, M.; Schäfer, J.; Robert, S.; Lafon, V. Roles of regional hydrodynamic and trophic contamination in cadmium bioaccumulation by Pacific oysters in the Marennes-Oléron Bay (France). Chemosphere 2011, 84, 80-90. [CrossRef] [PubMed]

161. Goddard, S.L.; Williams, K.R.; Robins, C.; Butterfield, D.M.; Brown, R.J.C. Concentration trends of metals in ambient air in the UK: A review. Environ. Monit. Assess. 2019, 191, 683. [CrossRef] [PubMed]

162. Kawamura, Y.; Tsuji, I.; Sugita, T.; Yamada, T. Migration of metals from stainless steel kitchenware and tableware. J. Food Hyg. Soc. Jpn. 1997, 38, 170-177. [CrossRef]

163. Kowalska, G.; Pankiewicz, U.; Kowalski, R. Determination of the level of selected elements in canned meat and fish and risk assessment for consumer health. J. Anal. Methods Chem. 2020, 2020, 2148794. [CrossRef] [PubMed]

164. Núñez, R.; García, M.Á.; Alonso, J.; Melgar, M.J. Arsenic, cadmium and lead in fresh and processed tuna marketed in Galicia (NW Spain): Risk assessment of dietary exposure. Sci. Total Environ. 2018, 627, 322-331. [CrossRef] [PubMed]

(C) 2020 by the authors. Licensee MDPI, Basel, Switzerland. This article is an open access article distributed under the terms and conditions of the Creative Commons Attribution (CC BY) license (http://creativecommons.org/licenses/by/4.0/). 